ББК 63.4

$$
\begin{gathered}
\text { Организация конференции и издание материалов проведены } \\
\text { при финансовой поддержке Российского фонда фундаментальных исследований, } \\
\text { проект № 19-09-20008 }
\end{gathered}
$$

Утверждено к печати Ученым советом ИИМК РАН

Редакционная коллегия тома II: А. В. Поляков, Е. С. Ткач (отв. редакторы), М. Т. Кашуба, Л. Б. Кирчо, Е. А. Черлёнок, В. Я. Стёганцева, А. И. Климушина

Рещензенты: д. и. н. Л. Б. Вишняцкий, д. и. н. А. А. Выборнов

Программный комитет конференции: академик РАН, д. и. н., проф. М. Б. Пиотровский (Государственный Эрмитаж, почетный председатель); д. и. н. В. А. Лапшин (ИИМК РАН, председатель); д. и. н. А. В. Головнёв (МАЭ РАН, сопредседатель); д. и. н. В. А. Дергачёв (Высшая антропологическая школа, Молдова, сопредседатель); д. и. н. И. Ф. Попова (ИВР РАН, сопредседатель); академик АН Республики Узбекистан, д. и. н., проф. Э. В. Ртвеладзе (сопредседатель); к. и. н. А. В. Поляков (ИИМК РАН, зам. председателя); к. и. н. В. А. Алёкшин (ИИМК РАН, зам. председателя); д. и. н. Ю. Е. Берёзкин (МАЭ РАН); Dr., Prof. Н. Бороффка

(Германский археологический институт, Германия); В. С. Бочкарёв (ИИМК РАН);

Dr. Э. Кайзер (Свободный университет Берлина, Германия); к. и. н. М. Т. Кашуба (ИИМК РАН); д. и. н. Л. Б. Кирчо (ИИМК РАН); к. и. н. А. В. Кияшко (Южный федеральный университет); к. и. н. П. Ф. Кузнецов (СГСПУ); к. и. н. Н. М. Малов (СНИГУ); к. и. н. В. П. Никоноров (ИИМК РАН); Ю. Ю. Пиотровский (Государственный Эрмитаж); д. и. н., проф. Д. Г. Савинов (Институт истории СПбГУ); к. и. н. В. Н. Седых (Институт истории СПбГУ); к. и. н. Н. Н. Скакун (ИИМК РАН); к. и. н. Н. Ф. Соловьёва (ИИМК РАН); к. и. н. А. И. Торгоев (Государственный Эрмитаж); к. и. н. Е. А. Черлёнок (Институт истории СПбГУ)

Организационный комитет конференции: к. и. н. А. В. Поляков (ИИМК РАН, председатель); к. и. н. В. А. Алёкшин (ИИМК РАН, зам. председателя); В. С. Бочкарёв (ИИМК РАН); к. и. н. М. Т. Кашуба (ИИМК РАН); д. и. н. Л. Б. Кирчо (ИИМК РАН);

А. И. Климушина (ИИМК РАН, отв. секретарь); к. и. н. В. П. Никоноров (ИИМК РАН); Ю. Ю. Пиотровский (Государственный Эрмитаж); В. Я. Стеганцева (ИИМК РАН); В. В. Терёхина (ИИМК РАН, МАЭ РАН, отв. секретарь); к. и. н. Е. С. Ткач (ИИМК РАН); И. Ж. Тутаева (Государственный Эрмитаж); к. и. н. Е. А. Черлёнок (Институт истории СПбГУ)

Древности Восточной Европы, Центральной Азии и Южной Сибири в контексте связей и взаимодействий в евразийском культурном пространстве (новые данные и концепции): Материалы Международной конференции, 18-22 ноября 2019 г., Санкт-Петербург. Т. ІІ. Связи, контакты и взаимодействия древних культур Северной Евразии и цивилизаций Востока в эпоху палеометалла (IV-I тыс. до н. э.). К 80-летию со дня рождения выдающегося археолога В. С. Бочкарёва. - СПб.: ИИМК РАН, Невская Типография, 2019. - 287 с.

ISBN 978-5-907053-35-9

DOI 10.31600/978-5-907053-35-9 


\title{
HORSE EQUIPMENT OF THE LATE BRONZE AGE IN EARLY CHINA: REVOLUTION AND EVOLUTION
}

\author{
Elena V. Stepanova, Konstantin V. Chugunov \\ The State Hermitage Museum, St. Petersburg, Russia
}

Keywords: driving chariot horses in the Bronze Age, evolution of horse bridle in Early China, interaction between the steppe and China.

This paper focuses on the reconstruction of a bridle set without bits for driving chariot horses. There are examples of bridles without bits in the Shan complexes of China - they also have no cheekpieces, but include metal or bone arcuate elements that might have been used as upper or lower elements of 'hakamors' (halters). The reins were attached to the ends of these elements. Bits appear in China only in the era of the Western Zhou under the influence of steppe cultures. The further evolution of horse bridle in China occurred independently. The next revolutionary changes took place here in the early Scythian time.

\section{ЖЕРТВОПРИНОШЕНИЕ В ЭПОХУ ПОЗДНЕЙ БРОНЗЫ (ПО МАТЕРИАЛАМ МОГИЛЬНИКА ТАРТАС-1 В БАРАБИНСКОЙ ЛЕСОСТЕПИ) ${ }^{1}$}

\section{Н. С. Ефремова}

Институт археологии и этнографии СО РАН, Новосибирск, Россия

DOI: 10.31600/978-5-907053-35-9-97-98

Ключевые слова: Барабинская лесостепь, андроновская культура, пахомовская культура, жертвоприношение, ритуальный комплекс, мировоззрение, духовная культура, производственные культы.

Тартас-1 - разновременный памятник, расположенный на территории Барабинской лесостепи в Обь-Иртышском междуречье, более десяти лет исследуется акад. В. И. Молодиным. Здесь обнаружены и погребальные, и хозяйственные, и ритуальные объекты, датирующиеся в широком диапазоне - от неолита до позднего средневековья. Отдельные объекты и единичные артефакты позволяют предположить существование в погребальной обрядности носителей древних культур ритуалов жертвоприношения.

Следы таких действий обнаруживаются в эпоху развитой бронзы. Так, в материалах из захоронений андроновской (фёдоровской) культуры основную часть находок составляют керамические сосуды. Присутствие посуды в могиле традиционно рассматривается исследователями как свидетельство существования в погребальном обряде идеи сопроводительной пищи. Однако единичные случаи локализации сосуда на уровне материка вблизи погребения могут свидетельствовать как о тризне, так и о жертвоприношении, особенно если учесть, что в данном случае сосуд был установлен вверх дном (Ефремова, Молодин 2016).

Уникальными в свете рассматриваемой проблемы являются ритуальные комплексы восточного варианта пахомовской культуры, локализованные на юго-западной периферии памятника (Молодин и др. 2012). На связь с погребальным обрядом указывает наличие поблизости захоронений данной культуры. Объекты представляли собой каркасностолбовые конструкции или скопления артефактов, расположенных на уровне материка и в небольших ямах. Имели место прокалы и теплотехнические сооружения. В числе находок - бронзовые наконечники копий, части литейных форм, костяные и каменные изделия, большое количество фрагментов керамики.

${ }^{1}$ Работа выполнена при финансовой поддержке РФФИ, проект «Древности» № 18-09-40028 «Модели иррациональной деятельности населения юга Западной Сибири в голоцене». 
Единичные ямы содержали кости животных, так, в одной из ям обнаружено 438 фрагментов, в том числе затылочная часть черепа лося (Ефремова и др. 2017). В ямах встречались также кости рыб. Дважды на площади ритуальных комплексов обнаружены антропологические остатки - фрагмент таза человека в скоплении костей коровы и пяточная кость среди фрагментов керамики в небольшой яме.

Таким образом, у носителей восточного варианта пахомовской культуры жертвоприношение играло значительную роль в культовом действе, что проявилось не только в присутствии жертвенной пищи и специфических находок, но и в наличии локализованного сакрального пространства, требовавшего возведения помещения для отправления ритуалов.

\title{
Литература
}

Ефремова Н. С., Молодин В. И. 2016. Один из сюжетов обрядовых действий в погребальной практике андроновской (федоровской) культуры (по материалам могильника Тартас-1) // ПАЭАСиСТ. Т. 22. С. 278-282.

Ефремова Н. С., Мыльникова Л. Н., Молодин В. И., Васильев С. К., Дураков И. А., Селин Д. В. 2017. Ритуальные комплексы восточного варианта пахомовской культуры: новые концепции интерпретации // ПАЭАСиСТ. Т. 23. С. 314-317.

Молодин В. И., Наглер А., Хансен С. и др. 2012. Ритуальные комплексы восточного ареала пахомовской культуры на памятнике Тартас-1 (Обь-Иртышская лесостепь) // ПАЭАСиСТ. T. 18. C 231-236.

\section{SACRIFICES IN THE LATE BRONZE AGE (AFTER MATERIALS FROM THE CEMETERY OF TARTAS-1 IN BARABA FOREST-STEPPE)}

Natalya S. Efremova

Institute of Archeology and Ethnography of the Siberian Branch of RAS, Novosibirsk, Russia

Keywords: Baraba forest-steppe of southwest Siberia, Andronovo culture, Pakhomovskaya culture, sacrifice, ritual complex, world views, spiritual culture, production cults.

Archaeological evidence suggests the presence of irrational world views related with communication with supreme powers in the ideological notions of bearers of early cultures. Along with ritual complexes, both settling and burial ones confirm this opinion. Among materials from burial grounds, the frequent finds of pottery can be interpreted both as the presence of food accompanying the funerary ritual and funerary feastings, as well as the practicing sacrificial rites. Occasionally, within the area of a cemetery are found objects seemingly unrelated to the funerary rite. A specific collection of artifacts, as well as their localization within the limits of a necropolis suggest a non-ordinary semantics of these structures. The presence of certain categories of finds makes it possible to connect the latter with practicing rituals of another type, e. g. hunting ones or even those related with metal casting, while the findings of separate bones of homo are possibly suggestive of human sacrifices.

\section{КЕРАМИЧЕСКИЕ КОМПЛЕКСЫ БРОНЗОВОГО ВЕКА НИЖНЕЙ АНГАРЫ: ПРОБЛЕМЫ ХРОНОЛОГИИ И КУЛЬТУРНОЙ ПРИНАДЛЕЖНОСТИ}

\author{
П. В. Мандрыка, П. О. Сенотрусова \\ Сибирский федеральный университет, Красноярск, Россия
}

DOI: 10.31600/978-5-907053-35-9-98-101

Ключевые слова: бронзовый век, Нижнее Приангарье, керамика, хронология.

Керамика бронзового века Нижнего Приангарья практически не исследована. Традиционно к эпохе бронзы относят посуду с «жемчужинами» и рубчатой поверхностью, но работы последних лет демонстрируют наличие в регионе и других керамических традиций. 